\title{
ESTRUTURA NORMATIVA DA LEI N. 6.729 SOBRE CONCESSÕES COMERCIAIS ENTRE PRODUTORES E DISTRIBUIDORES DE VEÍCULOS AUTOMOTIVOS TERRESTRES
}

\author{
Miguel Reale \\ Professor emérito da Faculdade de Direito da Universidade de São Paulo \\ Ex-Reitor da Universidade de São Paulo
}

Resumo:

O contrato de concessão comercial já adquiriu, no Direito brasileiro, uma configuração jurídica distinta, graças à doutrina e à jurisprudência. Dentre eles se destaca o contrato de concessão que rege as relações entre fabricantes e distribuidores de veículos automotivos terrestres, conforme as leis ns. $6.729 / 79$ e 8.132/90. O que distingue essas leis é o fato de serem completadas mediante "convenções de marca" e "convenções de categoria", cuja natureza e atribuições são examinadas pelo autor. Na parte final do trabalho, o professor Reale defende a tese de que devem ser aplicadas as normas gerais do Código Civil e leis complementares, no caso de ser omissa a legislação especial, sendo invocada nesse sentido importante decisão de nossos tribunais.

\begin{abstract}
:
The commercial concession agreement has already acquired, in the context of Brazilian Law, a different legal configuration, thanks to doctrine and jurisprudence. Among them, it is worth mentioning the concession agreement which governs relations between industrial companies and their distributors of ground automotive vehicles, pursuant to laws nrs. $6.729 / 79$ and $8.132 / 90$. The fact which distinguishes these laws is that they are complemented by "trademark conventions" and by "class conventions" whose nature and duties are studied by the author. At the end of his paper, professor Reale supports the thesis that the general rules of the Civil Code and its remainder complementary laws should be applied in the case of a legal gap on the part of the special legislation, having been invoked, in this sense, na important decision of our courts.
\end{abstract}

Unitermos: Convenções de marca e de categoria. 


\section{Princípios norteadores}

1. Além do Projeto de Código Civil que, depois de aprovado com emendas pela Câmara dos Deputados, se encontra há vários anos no Senado Federal, sem tempo para cuidar de matéria de tão-alta relevância, tenho tido a oportunidade de participar da elaboração de vários textos de constituições e de leis básicas do País, mas o estudo dos atos preparatórios da Lei n. 6.729, de 28 de novembro de 1979, bem como a colaboração na feitura de seu projeto inicial e em sua fundamentação jurídica, revestiram-se de características deveras singulares.

O problema da formação dos diplomas legais tem sido objeto de análise percucientes no plano da Ciência Política, da Teoria do Estado e do Direito Constitucional, surgindo eles sob os mais variados espectros. Leis há que surgem em virtude de momentâneos impactos emocionais, para atender a episódicos reclamos da opinião pública, sem prévias indagações de ordem racional, nos planos científico e técnico, existindo até mesmo normas legais que constituem mero fruto de combinações parlamentares de duvidosa legitimidade ética. Ao lado, todavia, desses e outros exemplos negativos, podemos, felizmente, lembrar grande número de casos em que a lei é o resultado de cuidadosas pesquisas anteriores, com base em dados objetivos da experiência social, visando a atender a altos interesses da coletividade. Nessas hipóteses, que preservam e consolidam a dignidade do Poder Legislativo, podemos afirmar, recordando aspirações de Jean Domat e de Jean-Jacques Rousseau, que "a lei é a razão escrita".

O pior é que qualquer que seja a gênese das leis, e por mais contrastantes que sejam seus motivos, legítimos ou espúrios, uma vez promulgadas, elas obrigam (lex prima facie valet) salvo se em conflito com os mandamentos constitucionais. Daí o dever do intérprete de inferir das leis boas todas as suas conseqüências benéficas e, em contrapartida, através de justificáveis processos hermenêuticos, atenuar os resultados maléficos das leis imperfeitas ou nocivas ao bem público.

Ora, a Lei que veio disciplinar a concessão comercial entre produtores e distribuidores de veículos automotores de via terrestre, inclui-se entre os exemplos de atos normativos dotados dos três requisitos que devem assinalar a legitimidade 
legal cabível na espécie, a saber: os relevantes objetivos visados sob o ponto de vista dos interesses individuais e coletivos; os altos valores de justiça ou de eqüidade a que se procurou atender; o prudente equilíbrio entre os direitos e interesses de ambos os grupos participantes da relação econômica regulada.

Esses princípios, que nortearam a elaboração da Lei n. 6.729, não foram aplicados, porém, de maneira abstrata, mas em direto contato com a experiência brasileira, atendendo-se às suas peculiares circunstâncias.

Longe de mim a idéia de que, no preparo do mencionado Anteprojeto de Lei, Renato Ferrari e eu tenhamos desprezado os exemplos da legislação alienígena, pois o Parecer que redigi, não após a elaboração do Projeto inicial apresentado pelo ilustre Deputado Salvador Julianelli, mas por ter participado de sua feitura, desde o início - demonstra o contrário.

Com efeito, no estudo por mim elaborado em junho de 1976, lembro vários precedentes de disciplina legal do assunto tanto na Europa quanto nas duas Américas, referindo-me até mesmo a projetos de lei em discussão em vários Parlamentos. Nesse sentido, veja-se o meu Parecer, publicado pela Associação Brasileira dos Distribuidores de Veículos Automotores (Abrave), 1976, p. 7 usque 39, depois inserto em meu livro Questões de Direito, São Paulo, 1981, pp. 109-48.

Ocorre, no entanto, que, ao contrário de fazermos mera sistematização ou aplicação de exemplos normativos estrangeiros, preferimos proceder a cuidadoso levantamento da questão nos quadros da economia nacional, levando em conta:

a. os documentos que, na época, disciplinavam as relações existentes entre as "montadoras" e os "distribuidores" de veículos automotores, para empregar a terminologia então corrente;

b. as situações de fato criadas em virtude do relacionamento em vigor entre as partes, à margem de qualquer interferência ou proteção estatal, possibilitando abusos de poder econômico;

c. a solução jurídica mais adequada ao superamento das desigualdades ocorrentes no setor, sem prejuízo dos interesses das empresas fabricantes e dos usuários.

Foi à vista dessas diretrizes básicas que foi elaborado o Anteprojeto de 1976, composto de 94 artigos, o que contrasta com os 37 da Lei que estou ora analisando, fato este que comprova a diferença entre o que se esperava obter e o que, a final, se alcançou, após o intempestivo veto aposto pelo Presidente Ernesto Geisel 
ao Projeto de Lei aprovado pelo Congresso Nacional, acolhendo, substancialmente, a proposta do Deputado Julianelli.

O certo é que não se compreenderá o real significado e alcance da Lei n. 6.729 - a que se deu o nome de "Lei Ferrari"- sem o devido estudo do mencionado Anteprojeto, não-somente por sua abrangência, com toda uma parte destinada à garantia dos direitos dos usuários (completamente suprimida) mas pela atenção que, na Hermenêutica Jurídica, deve ser dispensada aos precedentes históricos.

Razões da solução normativa aprovada

2. Atendo-me tão-somente ao texto da legislação em vigor, não há dúvida de que não havia caminho a ser seguido melhor do que a adoção da concessão comercial como figura jurídica destinada a reger as relações econômicas entre as montadoras e as distribuidoras de veículos automotivos terrestres.

Não estávamos, efetivamente, perante simples contrato de distribuição, que não é senão um caso complementar do contrato de agência, visto como, na estrutura econômica implantada na indústria automobilística brasileira, os chamados "distribuidores" na realidade, representavam empresários atuantes por conta e risco próprios, com direito de ver preservada a autonomia de sua empresa, no concernente à área de comercialização dos veículos livremente produzidos pelas montadoras, bem como de usufruir dos benefícios inerentes a essa produção com exclusividade, sempre com respeito a igual autonomia do fabricante no plano de sua iniciativa industrial e técnica.

O contrato de concessão comercial, em virtude de sua omniabrangência, combinando em unidade lógico-sistemática relações de mandato, agência, distribuição, compra e venda e fornecimento, na realidade altera cada uma dessas figuras jurídicas, na medida em que as correlaciona num modelo jurídico novo. Daí a dificuldade de defini-la, conceitualmente, prevalecendo noções de caráter mais operacional, nas quais a nota característica da "exclusividade" assume, geralmente, as formas mais diversas.

Não bastava, todavia, eleger a figura da concessão comercial como a mais adequada à regência das relações econômicas no setor da revenda de veículos automotores, visto como persistia sempre o risco das partes não chegarem a 
entendimento sobre seus direitos e deveres recíprocos, dada a hegemonia natural das "montadoras"

A Lei n. 6.729 surgiu, assim, em razão de plena consciência de haver uma estrutura oligopolística (a das "montadoras" de veículos) perante a qual os "distribuidores" se colocavam em visível desvantagem, sem condições de per si obterem o reconhecimento de normas contratuais reconhecedoras de seu autônomo status empresarial, na conclusão do contrato e ao longo de sua execução.

Eis aí a razão pela qual, no mencionado Parecer datado de 24 de junho de 1976, entendi necessário dedicar sua primeira parte ao estudo do fenômeno, mostrando que o capitalismo contemporâneo se caracteriza menos pela formação de monopólios do que pela criação de uma "economia de gigantescas unidades" (oligopólios) as quais, muito embora façam concorrência entre si, operam com natural e mútua entente, isto é, com base em acordos ou condições de comum interesse, não-raro de caráter reservado, quer em relação aos empresários que entrem em relação econômica com elas, quer perante o público consumidor.

Os oligopólios, observava eu, desenvolvem-se como distintos sistemas planetários, cada um deles com um centro de forças (a empresa industrial básica, instauradora e coordenadora do sistema) em torno do qual giram planetas e satélites (empresas complementares de diversos tipos) tudo orientado no sentido de explorar o mercado consumidor, em disputa de clientela entre vários sistemas. ${ }^{1}$

No caso particular da indústria automobilística é notável essa organização ganglionar de atividades econômicas, que abrange todo um universo de operações empresariais, descendo desde a alma mater do sistema, senhora por excelência da rede de veículos, até os usuários, através de elos intermédios representados, na área industrial, pelos "fabricantes de autopeças", e, no setor de comercialização, pelos "distribuidores ou revendedores" sem falar em numerosos satélites e minúsculos corpos acessórios, como as oficinas mecânicas nãooficializadas, os transportadores e fornecedores de combustível até os borracheiros urbanos ou de beira-de-estrada.

Inseridos nesse amplo contexto de interesses, os distribuidores dificilmente se liberariam dos processos que até então lhe haviam sido impostos e que consistiam, no mais das vezes, na aceitação, por adesão, de um contrato que estabelecia unilateralmente as condições a que deveria obedecer quem desejasse

1. Cf., outrossim, Miguel Reale - Política de ontem e de hoje, São Paulo, 1978, Ensaio I, p. 8 e ss. 
comercializar com exclusividade determinada marca de veículos. Como salientei no referido parecer, e me dispenso de repetir, tal contrato de adesão, em geral consubstanciado em mera carta-proposta do distribuidor, impunha a este inúmeros deveres, a talante da "montadora", sobretudo no que se refere à sua subordinação econômica, à obrigatoriedade de estoque, à aquisição compulsória de peças, participação em despesas de propaganda, e condições aleatórias de suspensão e cancelamento da avença.

3. Foram todas essas circunstâncias que encaminharam as pretensões das empresas revendedoras no sentido de obterem do Estado um diploma legal que instaurasse no País a obrigatoriedade do contrato de concessão comercial como base das relações entre "montadoras" e "revendedoras" de veículos automotivos terrestres.

Surgia, desse modo, uma notável experiência brasileira de dirigismo contratual que encontrava pleno apoio na Constituição de 1967/69, então em vigor, e que não conflita, como terei oportunidade de demonstrar, com a Carta Magna de 5 de outubro de 1988.

O dirigismo contratual assinala uma das grandes conquistas da chamada socialização ou humanização do Direito, tendo como razão de ser o propósito de estabelecer prévias e obrigatórias bases equiitativas ou de equilíbrio econômico entre as prestações recíprocas concluídas entre contratantes que, em virtude de múltiplas conjunturas, seriam obrigados a aceitar cláusulas leoninas se deixados entregues a si mesmos, no exercício de ilusória autonomia da vontade.

A autonomia da vontade é, sem dúvida, uma das grandes conquistas da vida jurídica, sendo expressão no mundo negocial da liberdade legalmente reconhecida a todo indivíduo. Ora, na fase do chamado "capitalismo selvagem", como uma das faces da economia fundada exclusivamente no "laissez faire, laissez passer" a autonomia da vontade converteu-se em verdadeiro dogma da experiência jurídica, quaisquer que pudessem ser as suas consequiências. $\mathrm{Na}$ realidade, chegou a se transformar em verdadeiro mito, em um princípio considerado intocável, regendo de maneira absoluta o mundo dos contratos, até que violentas transformações históricas, devidas sobretudo ao impacto tecnológico sobre a sociedade, vieram desmascarar acordos ilusoriamente realizados, sob pretensas bases de paridade, com falsa relação sinalagmática entre as partes contratantes.

Hoje em dia, há quem exageradamente condene a autonomia da vontade, pensando poder expungí-la do mundo do Direito. Trata-se, evidentemente, 
de equívoco manifesto, pois ela constitui uma categoria jurídica essencial, como alma que é o Direito das Obrigações, o que não impede de subordiná-la, quando imprescindível, a determinados pressupostos legais.

O dirigismo contratual, que encontrou insignes defensores no Direito francês, como Ripert, Josserand e Bonnecase, com ampla acolhida no Brasil, baseiase, tudo somado, no princípio de fonte pascaliana, assim expresso por Lacordaire: "entre o forte e o fraco, é a liberdade que escraviza e é a lei que liberta"

A bem ver, não se suprime a liberdade de contratar, mas se a subordina a determinadas normas impositivas de ordem pública. Não há dúvida, porém, que se impede a livre estruturação do conteúdo do contrato, a fim de salvaguardar o justo equilíbrio das prestações e contraprestações.

"Contudo, como pondera Orlando Gomes, reconheceu-se que, apesar da tendência para regulamentar o conteúdo do contrato, seu conceito não se modificou, dado que tem como elemento decisivo o consentimento livre. A essa conclusão chegou o próprio Josserand, esclarecendo que, se a lei não exige que o contrato decorra de uma discussão livre de suas cláusulas, contentando-se com o consentimento livre na sua conclusão, a regulamentação do contrato não o exclui, nem altera o seu conceito. No mesmo sentido, Carnelutti, justificando a persistência do conceito do contrato, distingue o concurso de vontades para a formação do vínculo da regulamentação das obrigações oriundas desse vínculo, para mostrar que o acordo de vontades basta para definir a natureza contratual do ato. $A$ regulamentação bilateral das obrigações não é o elemento essencial à conceituação do contrato. Pouco importa que resulte da livre discussão entre as partes, da preponderância de uma sobre a outra, ou da necessidade de adesão ao esquema legal". 2

2. Orlando Gomes, Contratos, Rio de Janeiro, 1959, p. 31 e ss. Cf., do mesmo autor, Transformações gerais do direito das obrigações, São Paulo, 1967. 
Consoante oportuna ponderação de Santiago Dantas, foi por influência do pensamento solidarista, nascido das transformações do Estado democrático, inspiradas nas idéias socialistas - que o saudoso jurista não reduzia às diretrizes marxistas que vieram sendo corrigidas as conseqüências desumanas do antigo liberalismo jurídico. ${ }^{3}$

Não é demais advertir que o neoliberalismo ou o liberalismo social não contesta a inteira procedência dessas restrições à liberdade de contratar, resultante da natureza das coisas.

Além dos fatores ético-políticos, lembrados por Santiago Dantas, foram profundas alterações nos planos tecnológico e econômico que vieram alargar o campo do dirigismo contratual com a prefiguração de contratos-tipo ou a exigência de inclusão nos contratos de adesão de determinadas cláusulas sob pena de ficar a avença desprovida de validade e eficácia.

Embora sem situar o problema apenas no campo do Direito econômico, pois ele se expande por todos os domínios das relações obrigacionais, lembro aqui a seguinte observação de Eros Roberto Grau no verbete dedicado à matéria na Enciclopédia Saraiva:

"com o advento das modernas técnicas de intervencionismo econômico, a teoria dos fundamentos do contrato é objeto de profunda reformulação, deixando de ser ele entendido como expressão da prerrogativa de criar o seu próprio direito, que o individualismo atribuía às partes contratantes. Sujeita-se a vontade dos contratantes, a todo instante, nos dias que correm, ao interesse público, demonstrando-o cabalmente a emergência de novas figuras contratuais, a necessidade de apreciar a validez dos contratos em presença de normas de direito público e o condicionamento de sua execução ao atendimento de disposições da mesma ordem $^{\prime 4}$

3. Santiago Dantas, Problemas do Direito Positivo, Rio de Janeiro, 1953, p. 21.

4. Ob, cit., v. 18 , p. 410 . 

distribuidores de veículos automotivos terrestres

4. No que se refere à Lei que estamos analisando, já lembrei as suas motivações econômicas que redundaram na consagração pelo legislador brasileiro de um contrato-tipo de concessão comercial, ao qual os produtores e revendedores de veículos automotores terrestres são obrigados a conformar as suas pretensões.

A análise do contrato-tipo configurado pela Lei n. 6.729 excede os objetivos que me proponho no presente trabalho, mas não será demais recordar alguns de seus elementos formadores, tais como:

a. predeterminação do que se deva entender por objeto da concessão $\left(\operatorname{art} .3^{\circ}\right)$

b. duração da concessão normalmente por prazo indeterminado, ressalvado o direito de ser concluído o contrato social por tempo determinado, não inferior a cinco anos, automaticamente convertido em por tempo indeterminado, se não denunciado por qualquer das partes nos 180 dias anteriores a seu termo (art. 21);

c. proibição de atos que importem na subordinação econômica ou administrativa do concessionário ao concedente, o qual não pode interferir na gestão dos negócios daquele (art. 16);

d. especificação dos direitos complementares dos concessionários $\left(\operatorname{art.} 4^{\circ}\right)$

e. garantias dos concessionários no concernente a área demarcada e a direito de exclusividade na comercialização do produto, ressalvados os casos de venda direta dos concedentes a consumidores especiais (art. 15); bem como o de livre escolha do consumidor (art. $5^{\circ}$, conforme redação dada pela Lei n. 8.132, de 26.12.96);

f. direito dos concessionários instalados na área de concorrer, em igualdade de condições com os demais interessados, quanto às novas concessões permitidas pela lei de regência (art. $6^{\circ}$ da Lei supracitada);

g. normas sobre direitos e deveres recíprocos de concedentes e concessionários quanto a fornecimento de quotas certas de mercadoria, manutenção e reajustes de estoques (arts. $7^{\circ} .9^{\circ}$ e 10 );

h. regras sobre pagamento do preço das mercadorias fornecidas (arts. 11 e 13, esta com nova redação);

i. disciplina das indenizações devidas nos casos de "resolução" (lato sensu) dos contratos por infração do concedente ou do concessionário (arts. 24, 25 e 26); 
j. representatividade de concedentes e concessionários por entidades representativas das categorias econômicas e das redes das diversas marcas (arts. 17, 18,19 , e $\S 2^{\circ}$ do art. 30 );

k. força de lei conferida às convenções de categorias e de marcas.

Creio que bastam esses frisantes exemplos para ficar caracterizado o contrato de concessão-tipo delineado, em pontos essenciais, num amplo quadro discriminativo de direitos e deveres, para reger as relações dos produtores e revendedores de veículos automotivos terrestres na área específica de comercialização, sem interferência no plano técnico da produção, que é de iniciativa privativa do concedente.

As disposições legais pertinentes à matéria supradiscriminada, como acontece nos casos de dirigismo contratual, têm caráter imperativo ou cogente, determinando o art. 30 que serão consideradas nulas as cláusulas contratuais que as contrariarem.

Caberá ao intérprete verificar, em cada caso, quando as avenças constantes dos contratos colidirem com os preceitos da Lei de regência, sendo certo que elas só poderão ser consideradas desprovidas de eficácia quando colidirem claramente com as normas legais, visto como, em se tratando de restrições à liberdade de contratar - que continua sendo o pressuposto normal da vida obrigacional elas somente podem ser interpretadas e aplicadas em consonância e nos limites das disposições expressas, não podendo prevalecer a interpretação extensiva. Isto porque, consoante acertado magistério de Carlos Maximiliano, o maior de nossos hermeneutas, "interpretam-se restritivamente as disposições derrogatórias do direito comum" 5

5. Hermenêutica e Aplicação do Direito, $10^{2}$ ed., Rio de Janeiro, 1988, §§ 286-288, p. 234 e ss. 
Natureza jurídica das Convenções previstas na Lei n. 6.729

5. Quando o legislador se decide a promulgar normas legais condicionadoras das estipulações contratuais, dois caminhos se the antolham: ou ele se limita a enunciar os princípios e diretrizes gerais; ou, então, prefere desde logo detalhar o conteúdo dos futuros contratos.

Manifestos são os inconvenientes da segunda solução, não-somente porque os atos normativos casuísticos se revelam na prática insuficientes, como também porque freqüentemente surgirão contradições entre as disposições mesmas e entre estas e as imprevistas ocorrências da experiência concreta.

$\mathrm{Na}$ hipótese, que estamos analisando, optou-se pela primeira solução, não-obstante, vez por outra, se tenha cedido à tentação de particularizar a determinação legal, nem sempre com o devido rigor técnico.

Além dessa opção quanto ao tipo de norma legal, verificava-se que, preferida a via genérica, seriam inevitáveis as divergências quanto à aplicação dos preceitos, ganhando relevo o problema das lacunas normativas, visto como, por se tratar de disposições derrogatórias do Direito comum, não podiam elas ser fruto de mero processo hermenêutico.

Punham-se, desse modo, quatro novas opções:

a. ou se deixava a questão em aberto, para solução das divergências na tela judicial, quando verificada a impossibilidade de composição amigável;

b. ou se preferia uma solução estatizante, confiando-se a um órgão do Ministério do Estado (como, por exemplo, o da Indústria e Comércio, ou outro de análoga competência) a que estivesse afeto a atribuição de resolver os conflitos emergentes na aplicação da Lei;

c. ou adotar uma solução mista, mediante convênios entre as partes interessadas, com recurso à autoridade administrativa, tal como previsto no Anteprojeto inicial;

d. ou, se cuidava de criar um sistema de solução dos conflitos "interna corporis", isto é, em virtude de órgãos representativos das próprias categorias econômicas interessadas. 
Ao fazer-se opção por esta quarta via, posso afiançar que o Direito pátrio inovava criadoramente na matéria, dando original e eficaz desenvolvimento à idéia corporativa, já lembrada para outros fins, como um dos processos de superar as deficiências de um grupo econômico mais fraco perante outro mais dotado de poder decisório.

Orlando Gomes faz referência ao processo corporativo, quando os interessados mais frágeis resolvem compor e unir suas forças para, desse modo, poderem contratar de igual para igual. Vale a pena transcrever o tópico em que aquele saudoso civilista trata do assunto, nestes termos:

\begin{abstract}
"O terceiro processo técnico é o mais interessante por importar regresso ao princípio da liberdade de contratar, mediante a restauração do equilíbrio de forças entre os contratantes. As pessoas que podem figurar numa relação jurídica como uma de suas partes organizam-se, fortalecendo-se, para que, na formação do contrato em que são interessadas, possam discutir as condições contratuais em pé de igualdade com a outra parte. Trava-se, então, a discussão corporativa, como ocorre, expressivamente, no contrato coletivo de trabalho. Esse processo técnico afasta a regulamentação autoritária, substituindo-a pela aquiescência livre dos interessados, no dizer de Henri De Page ${ }^{\prime \prime}{ }^{6}$
\end{abstract}

Mesmo antes da Lei n. 6.729, a indústria automobilística brasileira já havia vencido essa etapa de organização corporativa, tendo as montadoras e distribuidoras constituído as respectivas associações nacionais representativas de cada categoria, mas, é claro, de conformidade com o Direito comum, sem que essa representatividade tivesse caráter compulsório em relação a cada associado, e sem que as entidades possuíssem qualquer poder de natureza normativa.

Foi, porém, em razão desse fato, que nos ocorreu a idéia de, através das entidades nacionais existentes, conceber-se um sistema normativo complementar de natureza consensual e corporativa, resultado de entendimentos entre as duas

6. Orlando Gomes, Contratos, cit., p. 35. Cf., outrossim, H. De Page Traité Élémentaire de Droit Civil Belge, t. II, p. 431. 
categorias econômicas interessadas, a fim de particularizar ou especificar o texto legal genérico, assegurando-se a sua aplicação efetiva. Com o seu preparo jurídico e graças à sua longa experiência no setor automobilístico, Renato Ferrari, que se empenhara de corpo e alma na solução legal do problema, concebeu dois graus de convenções, a das categorias econômicas e a de marcas, cuja natureza jurídica cumpre elucidar.

Nunca será demais ressaltar a profunda alteração normativa operada com a promulgação da chamada Lei Renato Ferrari, denominação que representa justa homenagem em razão do obstinado empenho com que ele soube levar a bom termo uma não-fácil empreitada, afrontando sucessivos tropeços, e fazendo renascer das cinzas de um inesperado veto o texto, a final sancionado pelo Presidente João Figueiredo.

Normalmente, emanada uma Lei de natureza genérica, a praxe é a sua particularização, mediante Decreto regulamentar da competência privativa do presidente da República. Poder-se-ia ter seguido essa trilha habitual, mas desde logo se percebeu o risco de deixar a agentes burocráticos a elaboração de um regulamento eminentemente técnico, e, além do mais, sujeito a previsíveis adaptações que somente poderiam ser configuradas "in concreto" pelas próprias categorias econômicas interessadas, à luz e em função dos respectivos interesses.

Como era de esperar, a solução adotada não podia deixar de ser taxada de retrógado corporativismo, numa confusão lamentável com o corporativismo fascista que se inseria na estrutura de um Estado autoritário, deixando pouca margem de poder decisório às categorias econômicas, convertendo-as em "órgãos estatais"

Ao contrário, quando, no Estado de Direito, se transfere a entidades corporativas privadas o poder de dar execução ou aplicação à Lei que lhes disciplina as relações econômicas, o resultado é a descentralização da competência normativa, num pluralismo que se desenvolve à margem do poder estatal.

Nessa linha de pensamento, a corporação deve ser entendida quando dois ou mais segmentos econômicos se contrapõem em virtude de interesses distintos, mas, ao mesmo tempo, não podem deixar de ser solidários entre si em razão do empreendimento comum, sem cuja preservação e desenvolvimento não subsistiriam. Daí serem levados a delimitar democraticamente seus direitos e deveres recíprocos, dando origem a uma corporação, na qual se integram harmonicamente interesses associativos, visando à atualização da Lei que prevê a solução dos 
conflitos mediante convênios ou convenções, o que, evidentemente, não exclui, quando necessário, o recurso à via judicial.

Ainda não se procedeu ao estudo teórico da estrutura normativa da Lei n. 6.729, nem tampouco até agora se cuidou de determinar qual a natureza jurídica das convenções de categorias econômicas e das convenções de marcas, previstas no mencionado diploma legal. É o que pretendo fazer, oferecendo algumas soluções ao deslinde da matéria.

6. Trata-se de questão que, pela novidade do tema e por seu alcance, os antigos mestres italianos do início do século consideravam elegante. A elegantia iuris surge toda vez que um assunto jurídico se reveste de interesse ao mesmo tempo prático e teórico, envolvendo a elaboração de novas categorias jurídicas capazes de qualificar, com o possível rigor técnico, as soluções normativas consagradas pelo legislador para atender a circunstâncias emergentes da vida social e econômica.

Note-se, preliminarmente, que, na realidade, há dois problemas jurídicos complementares a serem esclarecidos: o da representação legal conferida às entidades de caráter nacional $\mathrm{e}$ às vinculadas a cada rede formada para comercialização de determinada marca de veículos: e o caráter obrigatório das convenções nascidas consensualmente da apontada representação.

É óbvio que, normalmente, as entidades representativas de uma categoria profissional ou econômica somente podem decidir e atuar em razão dos fins e nos limites previstos nas respectivas disposições estatutárias, tudo se desenvolvendo no plano das obrigações de ordem privada, vinculando os seus associados tão-somente quando os estatutos o determinarem. Na Lei n. 6.729, ao contrário, estamos perante entidades às quais é conferido um poder decisório de caráter normativo vinculante de todas as empresas associadas, como resulta do art. 17 que não é demais transcrever na íntegra, a saber:

"Art. 17 As relações objeto desta Lei serão também reguladas por convenção que, mediante solicitação do produtor ou de qualquer uma das entidades adiante indicadas, deverão ser celebradas com força de lei, entre:

I - as categorias econômicas de produtores $e$ distribuidores de veículos automotores, cada uma representada pela respectiva entidade civil ou, na falta desta, por outra entidade competente, qualquer delas 
sempre de âmbito nacional, designadas convenções das categorias econômicas;

II cada produtor e a respectiva rede de distribuição, esta através da entidade civil de âmbito nacional que a represente, designadas convenções da marca.

$\S 1^{\circ}$ - Qualquer dos signatários dos atos referidos neste artigo poderá proceder ao seu registro no Cartório competente do Distrito Federal e à sua publicação no Diário Oficial da União, a fim de valerem também contra terceiros em todo território nacional.

$\S 2^{\circ}$ Independentemente de convenções, a entidade representativa da categoria econômica ou da rede de distribuição da respectiva marca poderá diligenciar a solução de dúvidas e controvérsias, no que tange às relações entre concedente e concessionário."

Duas são as hipóteses previstas. Para a elaboração de convenções de categorias econômicas defrontam-se associações civis nacionais de produtores e distribuidores, ambas armadas de poderes para resolver em nome de todas as empresas nelas respectivamente congregadas; para as convenções de marcas, os entendimentos, também dotados de vis compulsiva, se realizam entre a empresa produtora e a entidade nacional representativa dos distribuidores vinculados à sua rede e à sua marca.

Estamos, por conseguinte, perante um caso singular de representação "erga omnes" conferida por lei, de tal modo que, uma vez assinada pelos "representantes legais" qualquer dos dois tipos ou graus de convenções, nenhuma empresa produtora, assim como nenhuma entidade ou empresa distribuidora, poderá se insurgir contra o que foi convencionado, salvo nas hipóteses de conflito com norma constitucional, com lei complementar ou ordinária de ordem pública (desde que aplicável à espécie) ou com dispositivo da própria Lei de regência.

A respeito dessa representatividade de ordem legal poderíamos lembrar o símile do sindicato representativo da categoria profissional ou econômica (Constituição de 1988 , art. $8^{\circ}, \mathrm{II}$ ), cujas convenções coletivas de trabalho obrigam também aos não-sindicalizados (cf. Consolidação das Leis do Trabalho, arts. 611 e ss.). 
Por esse exemplo se pode perceber como a representatividade associativa, de que trata a Lei Renato Ferrari, ultrapassa os lindes do mero Direito Privado, para produzir efeitos erga omnes próprios dos atos públicos. É, aliás, em virtude da força cogente genérica das convenções coletivas de trabalho que alguns juristas italianos chegam a dizer que, em tal caso, os sindicatos atuam como se fossem pessoas de Direito Público, o que não deve causar estranheza, tão tênue vaise tornando cada vez mais a distinção entre o Direito Público e o Privado, válidas mais como termos práticos de referência e não como campos radicalmente estanques.

Esclarecido, embora per suma capita, a natureza jurídica da representação configurada ex vi legis para dar nascimento às convenções de categorias econômicas e às de marca, resta ver qual a natureza jurídica delas.

Evidentemente, elas não têm caráter regulamentar, pois tanto na Constituição de 1967/69 quanto na de 1988, o regulamento constitui um ato privativo do Presidente da República e destina-se à fiel execução das leis (Carta Magna, art. 84, IV).

Poder-se-ia afirmar, que tais convenções "celebradas com força de lei" (caput do art. 17, supratranscrito) constituem atos normativos de natureza consensual corporativa dotados de imperatividade estabelecida com força de lei, não podendo, por isso mesmo, ultrapassar os limites traçados por sua razão de ser, que consiste em possibilitar a execução da Lei que as disciplina.

Estamos, em suma, perante o que os atuais estudos de Epistemologia Jurídica qualificam de subsistemas normativos, cuja elaboração se acha prevista em Lei, para os fins nela determinados.

Como subsistemas normativos, as convenções em apreço subordinamse aos ditames da Lei que lhes deu vida, não podendo inovar na Lei. Quanto a esse ponto, equiparam-se aos regulamentos que também não podem exceder os limites legais.

Não se trata, por conseguinte, de uma legislação complementar, constitucionalmente inadmissível, muito embora o art. 17 declare, com manifesta impropriedade técnica, que "as relações objeto desta lei serão também (sic) reguladas por convenções", o que poderia dar lugar ao entendimento de ser-lhes lícito acrescentar algo ao texto legal. 
Atribuições das convenções das categorias econômicas

7. Não há dúvida que a Lei n. 6.729, a convenção das categorias econômicas e a convenção de marca formam uma graduação escalonada de normas, de tal modo que elas se ordenam hierarquicamente, a segunda convenção se subordinando à primeira, e ambas à Lei. É o que determina expressamente o art. $1^{\circ}$ do Capítulo XXIV da Primeira Convenção das Categorias Econômicas, de 16 de dezembro de 1983, publicado no Diário Oficial da União de 13 de janeiro de 1983, firmada pela Associação Nacional dos Fabricantes de Veículos Automotores Anfavea e a Associação Brasileira dos Distribuidores de Veículos - Abrave, nos seguintes termos:

"Art. $1^{o}$ As normas e procedimentos estabelecidos pelas convenções de categorias econômicas prevalecem sobre as disposições das convenções de marca."

Todavia, como a Lei de regência delimita minuciosamente as esferas de competência das duas modalidades de convenções, o primado da convenção de categorias econômicas somente se dá quando a matéria é de ordem geral e não se enquadra expressamente entre as atribuições que o art. 19 confere às convenções de marca. Nesse campo, penso eu, devem ser seguidos os critérios em vigor na estrutura da República Federativa do Brasil, na qual as leis federais não prevalecem sobre as estaduais ou municipais quando a Constituição, como lei suprema, conferir a matéria à competência privativa dos Estados e Municípios.

$\mathrm{Na}$ Lei, que estamos analisando, não foram previstas competências concorrentes entre os dois tipos de convenções, mas outorga às convenções de categorias econômicas atribuição supletiva para estabelecer normas, até e enquanto estas não forem concluídas.

É o que se infere do $\S 2^{\circ}$ do art. $1^{\circ}$ do Capítulo XXIV da Primeira Convenção de Categorias Econômicas, supracitada, o qual dispõe:

"§ $2^{\circ} \quad$ Relativamente aos dispositivos de qualquer natureza das convenções das categorias econômicas, 
quando abrangerem matéria incluída pela Lei na competência das convenções de marca, poderá esta estipular normas e procedimentos específicos distintos daqueles previstos nas sobreditas convenções que melhor estabeleceram ou atendam os direitos $e$ interesses da respectiva rede de distribuição."

Aliás, também o inciso III do art. $3^{\circ}$ declara que as convenções das categorias econômicas podem

"III - dispor sobre matéria que a convenção de marca não tenha decidido ou regulado."

É manifesto, pois, em tal caso, o caráter supletivo de várias de suas disposições.

Não é meu propósito, no presente trabalho, tecer comentários aos arts. 18 e 19 que disciplinam respectivamente, os dois apontados tipos de convenções, mas sim apontar para algumas questões que poderão dar lugar a antinomias, ou a perniciosa multiplicação de disposições convencionais, tornando cada vez mais exígua a margem sempre profícua dos entendimentos in concreto.

Com propriedade, o inciso I do art. 18 da Lei n. 6.729, reza que as convenções das categorias econômicas se destinam a "explicitar princípios e normas de interesse dos produtores e distribuidores de veículos automotores"

O emprego prudente do verbo explicitar denota o reconhecimento pelo legislador de que existem na Lei princípios e normas implícitos, de sorte que complementando meu pensamento anterior me parece que as convenções, além de especificar as normas legais, para torná-las cada vez mais adequadas aos interesses recíprocos dos produtores e distribuidores, têm a atribuição de determinar quais são os princípios ou regras legais implícitos, quando não devidamente expressos.

O problema da explicitação das normas legais é eriçado de dificuldades, porque depende de uma série de pressupostos hermenêuticos. Como, porém, na hipótese estudada, a explicitação deve resultar do consenso de ambas as partes, tais dificuldades são superadas, desde que os preceitos exteriorizados não extrapolem dos ditames legais. Assim sendo, se uma convenção contiver disposições em conflito com a Lei, cada uma das partes poderá, a qualquer tempo, impugná-las, 
corrigindo-se o erro jurídico praticado, sem o que se chegaria à conclusão absurda de poder a norma convencional predominar sobre a norma legal.

Por outro lado, o legislador teve plena ciência de que a estrutura normativa por ele instaurada poderia ter não-somente lacunas, mas também albergar contradições, quando de sua aplicação, motivo pelo qual previu, nos incisos III e IV do art. 18 duas instâncias de solução de conflitos: a "decisão arbitral" e o juízo declaratório de caráter judicial.

Dessa matéria, a Primeira Convenção das Categorias Econômicas trata no mesmo Capítulo XXIV, não o fazendo, data vênia, de modo plenamente satisfatório. Cabia-lhe, com efeito, disciplinar melhor o procedimento a ser seguido pelas associações nacionais representativas dos produtores e distribuidores, a Anfavea e a Abrave ora Fenabrave, para chegarem a uma "decisão arbitral". Esta parece-me prevista como procedimento corporativo ou interassociativo, o que pressuporia a fixação prévia de normas disciplinadoras da escolha dos árbitros por aquelas entidades, suas atribuições, etc., ad instar do que ocorre no Código de Processo Civil com o juízo arbitral, ao qual as partes deverão recorrer "em caso de impasse" ou de descumprimento dos prazos previstos na convenção, quando se pretender alterar a convenção ( $\left(2^{\circ}\right.$ do art. $9^{\circ}$ do referido capítulo).

Como a Lei se refere, pura e simplesmente, a "decisão arbitral" para resolver as questões suscitadas pelos distribuidores e produtores, cumpria à Convenção das Categorias Econômicas explicitar esse dispositivo, inclusive esclarecendo que as questões controvertidas devem ser "resolvidas" mediante nova convenção, e não "submetidas" a ela, como, por evidente lapso, se declara no item III do art. 18. A bem ver, quem deve instaurar o procedimento arbitral corporativo são a Anfavea e a Fenabrave, a cada uma das quais caberia a eleição de seu árbitro, o que pressupõe a existência de um desempatador, ao qual é feita referência, mas, a meu ver, sem a desejável precisão técnica.

A propósito desse assunto, cabe ainda uma relevante observação. No mencionado Capítulo XXIV, é previsto o procedimento arbitral não apenas para resolver divergências entre as partes, em qualquer caso de interpretação das cláusulas em vigor, mas também na hipótese de uma das partes pretender alterar a convenção e a outra a ela se opuser. Nesse caso, é dito que, persistindo a divergência dos árbitros, caberá a decisão final a um desempatador, cujo pronunciamento obrigará a todos, passando a ser incorporado à Convenção das Categorias Econômicas (art. $7^{\circ}, \S 1^{\circ}$ ). 
Tal incorporação, contudo, não se opera automaticamente, dependendo de celebração de novo ato, dentro de 15 (quinze) dias $\left(\S 2^{\circ}, c\right)$, o que, evidentemente, não exclui que a parte, não-conformada com a decisão arbitral corporativa, prefira solucionar a questão em Juízo mediante a ação que julgar adequada, que poderá ser ou não o juízo arbitral, - ao qual se refere o $\S 2^{\circ}$ do art. $9^{\circ}$ do mencionado capítulo - pois é evidente que uma convenção de caráter privado não pode delimitar o direito de ação na tela judicial, inclusive porque, nos termos da Constituição, nenhuma lesão ou ameaça a direito pode ser subtraída à apreciação do Poder Judiciário (Constituição, art. $5^{\circ}$, item XXXV).

De qualquer forma, essa possibilidade de revisão das convenções graças a "decisão arbitral" ou a "juízo arbitral" - com base em argumentos válidos de fato e de direito - vem lançar nova luz sobre a natureza jurídica das convenções, confirmando, creio eu, o entendimento anteriormente exposto, distinguindo-as claramente dos "regulamentos legais", por mais que se lhes queira dar "força de lei"

Trata-se, em suma, de normas consensuais de natureza corporativa, obrigatórias por força de lei, mas suscetíveis de serem alteradas em virtude de novo consenso associativo, ou na falta deste, mediante "decisão arbitral" (corporativa) ou por via judicial.

Este ponto me parece de grande relevância, pois, enquanto um Regulamento tem eficácia até e enquanto não-revogado, ou revogada a Lei que ele explicita, as convenções, que estamos analisando, podem ser alteradas se uma das partes entender que há razões de fato e de direito supervenientes que exigem a sua mudança, o que pode determinar até mesmo uma demanda em Juízo, sendo visível a sua complexidade.

8. Sem proceder a meticuloso comentário da Primeira Convenção das Categorias Econômicas, pondero que ficou acertadamente estabelecido que a "decisão arbitral" e o "juízo declaratório" a que se referem o inciso III e IV do art. 18 da Lei de regência competem exclusivamente às Associações Civis de $2^{\circ}$ Grau (Anfavea e Fenabrave) mesmo porque o mencionado inciso IV prevê que "os assuntos pertinentes às convenções de marcas" no que se refere a juízo declaratório, se situam no âmbito das convenções das categorias econômicas.

O que o legislador pretende, em suma, é evitar a multiplicação desnecessária de decisões arbitrais ou de juízos declaratórios à revelia das entidades máximas representativas, sem se verificar, preliminarmente, a possibilidade de um acordo superior entre elas, dirimindo as dúvidas surgidas, ou dando entendimento de 
consenso às cláusulas convencionais. Desse modo, a empresa produtora e a respectiva Associação de marca não podem ingressar diretamente em Juízo para elucidar, mediante juízo declaratório, dúvidas suscitadas por convenção de marca, pois assim o determina o item IV do lembrado art. 18 da Lei. Caberá as entidades representativas das categorias econômicas apreciar a matéria, entendendo ou não necessário instaurar Juízo declaratório, por não terem encontrado uma solução de consenso.

Dessa posição eminente das Convenções das categorias econômicas, a Anfavea e a Abrave, ao assinarem a sua Primeira Convenção de 16.12.1983, inferiram que o produtor e a associação de marcas podem solicitar seu pronunciamento para, em conjunto,

"proferir decisão em grau de recurso." (art. $3^{\circ}$, item IV).

Lembre-se, outrossim, o art. $4^{\circ}$ desse mesmo capítulo que assim dispõe:
"Art. $4^{\circ}$ Entre as matérias que cabe à convenção das categorias econômicas decidir ou regular (sic) incluem- se:
I - os assuntos ou questões, dúvidas ou controvérsias que sejam apresentados pela entidade representativa da categoria econômica dos produtores, pela entidade representativa da categoria econômica dos distribuidores, por produtor ou por associação de marca.

A ambiguiidade desses textos não poderá deixar de dar lugar a divergências e perplexidades. Em primeiro lugar, não se recorre a uma "convenção", mas sim ao órgão ou órgãos que as editam. Por outro lado, parece-me sem sentido que, para solução de qualquer dúvida ou controvérsia, se deva lançar mão de uma "convenção de categoria econômica", com toda a complexidade que esta nova figura jurídica comporta.

Parece-me, pois, necessário, interpretar os lembrados dispositivos aceitando-se o poder recursal das entidades inferiores às superiores, às quais caberá resolver de comum acordo, devendo essa sua decisão ser incluída no texto da 
Convenção de Categorias Econômicas. Como o art. 18, I, da Lei de referência confere a estas também a finalidade de "explicitar princípios e normas", creio que se pode construir sobre esse preceito o poder recursal para as entidades de grau superior. Não excluo, todavia, que a questão possa dar lugar a controvérsias.

9. Examinando o texto da Primeira Convenção das Categorias Econômicas, verifico que os seus emanadores usaram amplamente de sua competência para "explicitar princípios e normas", fazendo-o, às vezes, com competência originária privativa e, outras, supletivamente, na ausência de convenções de marcas.

Entre os princípios explicitados figura o de conceito de consumidor, efetivamente essencial, pois estamos perante uma concessão comercial, cujo último elo é representado pelo usuário dos veículos ou de seus componentes, não raro confundido com o mero adquirente.

Parece-me feliz a noção de consumidor fixada pelo art. $6^{\circ}$ do capítulo I da mencionada convenção que reza:

"Art. $6^{\circ}$ Considera-se consumidor todo e qualquer adquirente dos bens relacionados na Lei, em seu art. $2^{\circ}$, destinando-os ao seu próprio uso e todo e qualquer contratante ou usuário da assistência técnica ou serviços concernentes aos mesmos bens.

Parágrafo único Quanto aos bens referidos naquele artigo:

a. - inciso III, considerar-se-á consumidor também o adquirente pessoa jurídica ou pessoa física a esta equiparada, cuja atividade ou objeto social relativos àqueles bens não estabeleçam ou caracterizem o comércio ou revenda dos mesmos;

Por aí se vê que a Lei n. 6.729 não interfere na esfera técnica da produção industrial, nem priva o produtor do poder de iniciativa no que tange à fabricação de componentes destinados a outros produtores, que não se destinem ao seu próprio uso, ou à revenda tais como foram fabricados, mas sim a integrar veículos ou equipamentos estranhos à rede que comercializa determinada marca. 
Esse entendimento é confirmado pelo art. 11 do mesmo capítulo I, quando dispõe:

"Art. 11 - Entende-se por produtos conflitantes aqueles de marcas diversas que, identificados por iguais características técnicas e finalidade, sejam concorrentes na mesma faixa de mercado.

Como se vê, as questões são claramente situadas no plano da comercialização, sem privar o concedente de sua posição eminente no que se refere ao plano industrial, conforme esta justa ponderação de Jean Guyénot, quando afirma:

"A supremacia técnica do produtor. Ela está implícita em sua função. Não se manifesta apenas no estágio da fabricação, mas igualmente no estágio da distribuição. $O$ interesse do produtor é o de zelar pela formação técnica dos concessionários, de tal modo que nenhuma característica ou inovação de fabricação não lhes escape, nas suas relações com a clientela. $O$ predomínio técnico do produtor sobre as firmas concessionárias é tanto mais forte quanto mais elevada a tecnicidade do produto (...). Esses dois fatores conjugados, um de ordem econômica, outro de ordem técnica, asseguram a hegemonia do produtor na direção da rede. Ele é o único em condições de exercê-la." (Les contrats de concession commerciale, Paris, 1968, p. 342 Sublinhei).

Lembro esse ponto para delimitar o âmbito da comissão comercial, prevenindo contra a tentação de ilícitas interferências na esfera técnica da produção que a Lei n. 6.729 claramente reserva ao produtor que pode alterar ad libitum a fabricação dos tipos de veículos, bem como oferecer novos ao mercado: o que a Lei assegura é o direito que tem o distribuidor de estender aos produtos novos ou modificados o seu direito de comercialização exclusiva, ressalvados os casos legais previstos, e sempre que a mercadoria se destine efetivamente a consumidor, tal como conceituado no texto da Convenção supratranscrito. 
Dei esse exemplo de explicitação de princípio, constante da Primeira Convenção das Categorias Econômicas, mas poderia aduzir outros, como às noções de "área demarcada", entendida, no art. $8^{\circ}$ do capítulo $1^{\circ}$, como simples "circunscrição geográfica", quando, na realidade, é uma "circunscrição geoeconômica", dada a possibilidade de mais de um concessionário desenvolver nela suas atividades; de "capacidade de mercado" conceitos que auxiliarão a melhor interpretação da Lei, assim como os relativos a "assistência técnica" ou a "contratação de novas concessões" etc.

Aliás, mesmo quando a Convenção das Categorias Econômicas dispõe sobre matéria pertinente às Convenções de Marca, elas têm a função, ou de suprir a falta destas ou de fornecer contribuição de inegável alcance hermenêutico.

Como já adverti, não é meu escopo comentar qualquer das convenções em vigor, limitando-me a externar meu ponto de vista sobre sua posição na estrutura normativa da Lei n. 6.729.

\section{$\mathrm{V}$}

As Convenções de Marca

10. As Convenções de Marca, nos termos do art. 19 da Lei de Regência, cuidam de problemas mais concretamente vinculados à concretude das relações entre concedentes e concessionários.

Analisando os 18 itens do mencionado artigo, verifico que a Primeira Convenção das Categorias Econômicas antecipou-se a discipliná-los, não-apenas firmando conceitos gerais, mas prevendo normas de procedimento.

Isto, contudo, não prejudica a competência das empresas e das associações de marcas, porquanto, ou aquelas disposições têm sentido genérico, ou valem como normas supletivas, sem falar, repito, em seu valor hermenêutico.

O objeto das convenções de marca é o mais amplo possível, até o ponto que o seu maior risco é descambar para o casuísmo, o qual, longe de facilitar os entendimentos e operações, não raro os dificulta.

Pelo estudo dos diversos incisos do art. 19 fácil é constatar que o seu objetivo fundamental é assegurar o equilíbrio econômico da concessão, garantindo ao distribuidor imediato acesso às fontes produtivas na proporção de sua capacidade 
de comercialização, evitando alterações que possam subverter as expectativas do mercado.

Uma concessão para distribuição de veículos automotores pressupõe sempre uma série de garantias, a primeira das quais é a duração do empreendimento, de tal modo que possa o capital investido receber a justa e esperada retribuição, o que somente é possível se o contrato não estiver exposto a experiência que venham privá-lo de normal exiqüibilidade.

Compreende-se, desse modo, a prudência com que se deve prever a quota de veículos a serem fornecidos, seus reajustes anuais, podendo-se dizer que a garantia de quota firme, como fornecimento mínimo, é a alma da concessão.

Não há dúvida que o distribuidor deve fazer tudo que estiver a seu alcance para atingir os índices máximos de comercialização, em benefício próprio e da respectiva rede, mas seria absurdo que o produtor pudesse lhe impor o recebimento de veículos ou componentes a seu bel talante, transferindo-lhe praticamente os riscos do mercado, uma vez que, pelo sistema predominante, as vendas se realizam à vista, em virtude do processo de financiamento vigente no setor, ponto este a que dei realce no Parecer de 1976.

É natural, por conseguinte, o cuidado com que as convenções de marca procuram cercar os problemas de formação e alteração de estoques, e os critérios que devem presidir a formulação dos pedidos de fornecimento de mercadorias e seu pronto atendimento, na medida das possibilidades técnicoeconômicas do produtor, conforme as conjunturas do mercado.

Nesse, como nos demais casos, o princípio de bilateralidade deve reger as relações entre produtor e distribuidor, podendo-se afirmar que àquele princípio agrega-se o de proporcionalidade, uma vez que as distintas capacidades de comercialização das empresas legitimam fornecimentos desiguais.

O certo é que, graças às várias cautelas enumeradas no art. 19, e que as convenções de marcas particularizam, é possível estabelecer-se um sistema de relacionamento entre concedente e concessionário marcado por justo equilíbrio.

Nesse relacionamento está afastado, por incompatível com a lei, toda forma de subordinação econômico-administrativa do distribuidor ao produtor, mas não é dito que aquele não deva obedecer a determinados requisitos, sobretudo de ordem técnica, estabelecidos pelo concedente, bem como que ele esteja desobrigado de requisitos de natureza empresarial ou administrativas ditadas pelo interesse 
comum da fábrica e de sua própria rede. Princípio de responsabilidade empresarial, eis outra diretriz ético-econômica que deve presidir o contrato de concessão.

\section{VI}

A Lei n. 6.729 e a legislação comum

11. Na aplicação da Lei n. 6.729 surgiam dois problemas correlatos de grande relevância, implicando a discussão de temas sobre a responsabilidade civil do produtor e do distribuidor quanto à indenização cabível resultante de culposa denúncia da concessão.

A primeira dessas questões diz respeito à interpretação a ser dada ao inciso IV do art. 24, o qual, após enumerar várias reparações, a que o concessionário tem direito quando rescindido o contrato indevidamente pelo concedente, acrescenta que este deva pagar o previsto nos itens I a III,

"satisfazendo-lhe (ao distribuidor) outras reparações que forem eventualmente ajustadas entre o produtor $e$ sua rede de distribuição."

O segundo problema é de maior amplitude, referindo-se à possibilidade de se recorrer ao Direito Civil para reparação de danos comprovados, mas não-enquadrados nos quatro incisos do mencionado art. 24.

Ambos os assuntos já foram objeto de pronunciamentos doutrinários e jurisprudenciais, inclusive a nível do Supremo Tribunal Federal, merecendo destaque o caso de que participei, na qualidade de parecerista, envolvendo a concedente Volvo do Brasil Motores e Veículos S.A., do Paraná, e a concessionária Fercoi Diesel S.A., antes sediada em São Paulo.

A hipótese é deveras elucidativa, pois versou, ao mesmo tempo, sobre a existência de praxe vigente na rede Volvo no sentido de dever o distribuidor construir o prédio destinado à concessão com base em projeto de arquiteto de exclusiva confiança do concedente e sob sua direta fiscalização; e sobre o delicado problema de, em havendo Lei especial, ser lícito recorrer ao Direito comum a fim de configurar-se a reparação de dano não-contemplado pela legislação de especial regência. 

distribuidores de veículos automotivos terrestres

A tese defendida pela Fercoi foi a de que, inopinadamente e sine causa, antes mesmo de ser assinado o contrato de concessão, esta lhe fora cassada, sem tempo para cobrir-se do altíssimo investimento realizado na construção do prédio. Entre os elementos componentes da indenização devida a Fercoi inclui o valor da diferença entre a área construída, conforme projeto elaborado pelo arquiteto da Volvo, e aquela que corresponderia ao seu ius aedificandi, isto é, ao seu direito de construir, dando ao terreno outra destinação, de acordo com o potencial de edificação assegurado pelo Código de Obras da Capital de São Paulo.

Nenhuma dúvida houve sobre a reparação fundada nos incisos I a III do já lembrado art. 24, mas a Volvo se insurgiu contra a pretensão da Fercoi relativa ao aproveitamento deficitário do terreno, alegando, em síntese, que:

a. nenhuma indenização poderia ser exigida além das previstas na Lei especial;

b. conforme antiga parêmia, exceptiones sunt strictissimae interpretationis;

c. era incabível invocar o inciso IV, por inexistir "ajuste" na rede sobre o assunto.

Convidado a manifestar-me sobre a matéria, elaborei um parecer, datado de 3 de maio de 1984, no qual analiso sobretudo o sentido do item IV; e, em 29 de maio de 1988, um parecer complementar destinado especialmente ao estudo das leis especiais perante o Direito comum, na tela da responsabilidade civil.

Adianto, desde logo, que a tese sustentada pela Fercoi foi vencedora, da $1^{\text {a }}$ à última instância, e até mesmo em ação rescisória de acórdão da Suprema Corte, como se verá a seu tempo.

Lembro, por ora, o tópico da sentença prolatada pelo então titular da $13^{\mathrm{a}}$ Vara Cível da Comarca de Curitiba, a 13 de junho de 1984, nos seguintes termos:

"Para a concessão, a A. teve que adquirir o terreno, fazer a construção nos termos do projeto e orientação da Volvo conforme esclarece o Sr. Perito, às fls. 418 da Medida Cautelar.

Foi deixada parte do terreno, não edificado, para servir de páteo de estacionamento e manobra de veículos. 
Na época em que foi realizada a perícia, não havia aproveitamento da construção e esta, na forma em que se encontrava servia para outra atividade comercial, requerendo, entretanto, adaptações vez que a construção foi feita visando uma atividade específica, com características muito especiais.

Por tudo que dos autos consta, com a rescisão do contrato, houve prejuízo à A., face o valor da diferença da área construída para o fim específico, com a capacidade de imóvel para fins comerciais.

A demolição, construção, ou reforma para readaptála ou reformá-la para nova atividade comercial também é prejuízo para a A., este causado pela rescisão do contrato existente entre ela e a $R$.

A reparação de danos deve cobrir todo o prejuizo causado pela $R$. à A., pelo que, defiro tal pedido, que deve ser objeto de execução de sentença."

Contra essa sentença foi interposta Apelação para o E. Tribunal de Justiça do Estado do Paraná (Apelação Cível n. 1.555/84 de Curitiba) tendo os Desembargadores da $3^{\mathrm{a}}$ Câmara Cível prolatado, a $1^{\circ}$ de outubro de 1985, o Acórdão n. 3.435, de que foi Relator o Des. Plínio Cachuba, negando provimento ao recurso de conformidade com a seguinte expressiva ementa:
"Apelação Cível. Ação Ordinária. Aplicação dos artigos 159, 1.056, 1.059 e seguintes do Código Civil, 24 e incisos da Lei 6.729, de 26 de dezembro de 1979, 274 e seguintes do Código de Processo Civil. Procedência em Primeiro Grau.
Irrecusável, no caso concreto, que a indenização deva ultrapassar os limites da legislação própria, pois, em caso contrário, resultaria em indenização insuficiente, injusta e a recorrida não ficaria inteiramente ressarcida dos prejuízos sofridos. Recurso Desprovido." 

distribuidores de veículos automotivos terrestres

Não conformada com essa decisão, a Volvo recorreu extraordinariamente ao V. Supremo Tribunal Federal, onde a sua Primeira Turma, com base no voto do Relator, o eminente Ministro Oscar Dias Corrêa, houve por bem confirmar a decisão de $2^{\mathrm{a}}$ instância, por entender que a referência a "outras reparações": feita no inciso IV da Lei n. 6.729, abria campo ao exame da matéria in concreto à luz do Direito Civil, com a afirmação, para fim lisonjeira, de que o acórdão do Tribunal de Justiça do Paraná se situara na linha do Parecer de minha autoria (Recurso Extraordinário n. 110.607-7 - RTJ 119/460).

Do referido acórdão destaco o seguinte trecho, após demonstrar que não cabia a argüição de negativa de vigência do inciso III do art. 24 , que fora bem aplicado pelo acórdão recorrido:

"É inegável, nessa linha de raciocínio, que, ao contrário do que sustenta a petição de recurso, ao ignorar o inciso IV do artigo 24, prevê ele outras reparações, além das do inciso III. E foi no exame da hipótese, do caso concreto, que o acórdão ampliou o estatuído no inciso III, com o que não lhe negou vigência, antes o aplicou, estendendo-lhe o efeito a outras reparações, que teve por devidas." (Ação Rescisória n. 1.273-9-PR, do Supremo Tribunal Federal - Serviço de Jurisprudência, D.J. 18.08.89 Ementário n. 1.551-2).

12. Assim sendo, parece-me de toda conveniência transcrever, no presente trabalho, os tópicos essenciais do mencionado Parecer, do seguinte teor:

"É irrecusável, pois, o ajuste concluído entre a Volvo e a Fercoi no tocante à exigência de construção de determinado edifício, tendo aquela levado a bom tempo a obrigação assumida, como limpidamente resulta dos laudos do Perito do Juízo e do Assistente da Autora. Reconhecido foi, outrossim, pelos vistores, que o terreno de $10.000 \mathrm{~m}^{2}$ não teve a utilização que as leis municipais de São Paulo possibilitavam, dada a sua específica e dirigida destinação, com o obrigatoriedade 
de deixar livre grande área "para servir como páteo de estacionamento e manobra de veículos" (fls. 418).

"Mas há mais. Tudo o que acabo de expor não resultou de mero ajuste entre a Volvo e a Fercoi, pela simples razão de que a exigência de "construção dirigida pela concedente, à custa da concessionária" constituía conditio sine qua non da outorga de qualquer concessão.

"Tratava-se, em suma, de praxe vigente na rede Volvo, ou seja, de obrigação acertada e imposta pela Volvo, como produtora, a toda a sua rede de distribuição.

"Alegar-se-á, todavia, que o inciso IV do art. 24 da Lei de regência não prevê expressamente reparações decorrentes da abrupta denúncia do contrato de concessão, antes que o tempo decorrido permita ao distribuidor cobrir as despesas relativas à construção imperativamente ajustada, ou seja, sem ter tido tempo para proceder a amortização do "quantum" por ele investido.

"Isto seria, no entanto, interpretar o inciso IV ao pé da letra, sem levar em conta o seu espírito, ou as razões ético-econômicas que o determinaram, quando entra pelos olhos que a ilícita e inopinada denúncia de uma concessão essencialmente vinculada à construção de obras de fim específico e próprio importa necessariamente reparação.

"Não é necessário, em matéria de dano ocorrido, que o legislador lhe explicitar as causas e as conseqüencias: estas resultam da natureza das coisas, isto é, da estrutura e da conformação daquilo que foi convencionado e que implica determinados efeitos de iure.

"O mal é que as grandes empresas, sobretudo as inseridas em grandes oligopólios, pensam ser-lhes lícito 
impor condições ad libitum, pouco se importando se os onerosos encargos, constituídos em seu benefício, redundem em dano para aqueles que com elas contratam.

"Assim sendo, penso eu que o caso da Consulta se integra plenamente no item IV do art. 24 da Lei de regência, surgindo a obrigação de reparar o dano resultante do não-uso da edificação imposta , como decorrência natural da comprovada rescisão de uma concessão comercial, por culpa do concessionário.

"Nem se repita, por ser equívoco há muito tempo superado, que as leis especiais são de interpretação estrita, repetindo-se o antigo brocado: exceptiones sunt strictissimae interpretationis.

"Eduardo Espinola, no seu Sistema de Direito Civil Brasileiro, invocando ensinamentos de Pescatore, Windsheid, Chironi, De Ruggiero, insurge-se contra essa visão estreita, afirmando que

'ao jus singulare não deve se referir a proibição de uma aplicação extensiva ou por analogia. Os conceitos contidos nas leis singulares devem produzir efeito em tudo e por tudo. Assim procederam sempre em todos os casos os próprios romanos." (Ob. cit., $4^{a}$ ed., Rio, 1960, v. I, p. 107, nota 48).

"A propósito, lembra Espínola a lição de De Ruggiero de que

'o direito singular é, como o direito normal, plenamente capaz de extensão, porque onde a ratio especial, que é seu fundamento, se apresenta, deve valer o mesmo preceito do direito, e não poderia receber aplicação o direito normal." (loc. cit.).

"É a luz dessas diretrizes hermenêuticas que deve ser interpretado o inciso IV do art. 24, inclusive, como já assinalei, pelo seu caráter complementar em relação aos modos de reparação discriminados no item anterior. 
"Admitindo-se, porém, ad argumentandum, que a espécie não se enquadrasse no mencionado inciso IV o que me parece desarrazoado nem por isso deixaria de haver razão bastante para a reparação do dano.

"A afirmação de que a Lei especial exclui a aplicação da Lei geral não se subordina à hermenêutica estrita que lhe quer atribuir a Volvo, invocando ensinamentos aplicáveis tão-somente na hipótese de regular ou normal aplicação do Direito.

"Quando, ao contrário, nos defrontamos com a ocorrência de culpa, e de culpa grave, tal como se dá no caso da presente Consulta - onde a carência de fatos legitimadores da intempestiva denúncia se soma a um revide ou represália moralmente condenável -, abre-se o campo dos princípios reguladores da indenização, ou seja, sob pena de haver dano sem reparação, o que é inadmissivel em Direito.

"As leis especiais não surgem para substituir draconianamente a legislação comum, mas sim para atender a peculiares configurações de dado campo de relações jurídicas: toda vez que se transcende esse domínio específico, pela verificação da ilicitude de um ato eivado de vício, do qual resulta dano para uma parte, em detrimento de outra, cujos direitos são sacrificados, com o locupletamento sine causa do causador do dano, dá-se a incidência dos princípios e das normas gerais: no caso, há que recorrer às normas gerais do Direito Civil e do Comercial, que não permitem haja dano sem reparação."

13. É no já mencionado parecer complementar que trato mais amplamente do problema do complemento da Lei especial pelo Direito comum, na hipótese de haver dano comprovado, mas não previsto naquela. Eis o que então escrevi:

"Ao contrário do que se sustenta, o ius singulare não é incompatível com a interpretação extensiva, nem com 
a aplicação da analogia, nos casos em que esteja comprovado um dano e a lei especial seja omissa. Como penso ter demonstrado, os quatro incisos do art. 24 da Lei $6.729 / 79$ não podem ser interpretados restritivamente, como "cláusulas penais" (tal como se chegou a dizer...) visto como expressam todos formas compensatórias do dano sofrido, ainda que "eventualmente", como se acha implícito no item IV.

"Todo o equívoco em que, data vênia, labora a Recorrente resulta da confusão entre direito excepcional e direito especial ou particular, para, desse modo, considerar a Lei de referência insuscetivel de ser completada graças à aplicação extensiva ou analógica do Direito comum, onde e quando necessário resultar da natureza das coisas.

Não devemos, com efeito, olvidar a sábia distinção que, nessa matéria, é feita pelo mestre Carlos Maximiliano, a saber:

'O recurso à analogia tem cabimento quanto a prescrições de Direito comum; não do excepcional, nem do penal. No campo destes dois a lei só se aplica aos casos que especifica.

$O$ fundamento da primeira restrição é o seguinte: $o$ processo analógico transporta a disposição formulada para uma espécie jurídica a outra hipótese nãocontemplada no texto; ora, quando este só encerra exceções, os casos não-incluídos entre elas consideramse como sujeitos à regra geral.

Não se confunde, entretanto, o Direito excepcional como o especial ou particular; neste cabem a analogia $e$ a exegese extensiva. (Hermenêutica e Aplicação do Direito, $9^{a}$ ed., 1979, p. 213).

"Como se vê, não é admissível confundir lex specialis com lex exceptionalis, pois é apenas e tão-somente nos 
"casos excepcionais" que se poderia falar em "maximum" de reparação, prefixado em lei.

"Adriano de Cupis não discrepa, aliás, desse entendimento, pois, antes de se referir, à p. 381 de sua clássica monografia, à limitação do "dano indenizável mediante um maximum constituído por uma cifra determinada por lei" advertira, no início do capítulo, à p. 182 que iria analisar os Casos Excepcionais em que não são aplicáveis "os critérios normais de ressarcimento" ou textualmente:

'Dobbiamo procedere all'esame dei casi, eccezionali (sic), in cui esso (il danno) é determinato o misurato com criteri diversi da quelli normali.

"E, linhas abaixo, volta a insistir:

'il diritto può ritenere equo e conveniente che in certi casi, l'entità del danno da reprimirsi giuridicamente si determini, ovvero si misuri, secondo criteri d'eccezione. (Il danno, $2^{a}$ ed., Milão, 1966, loc. cit. - Meus grifos).

"Não é o que se dá com o disposto no art. 24 da lex specialis 6.729/79, a qual, em quatro incisos, e não apenas em três, estabelece, nos de ns. I a III, critérios de indenização, e, no de n. IV, prevê Outras Reparações, conforme as características dos "ajustes eventuais".

"Assim sendo, uma lei especial não constitui um "campo cerrado", infenso à penetração dos ditames do jurídico e do justo, máxime em se tratando de matéria de responsabilidade civil, onde resplende o pressuposto ético de que 'onde há dano deve haver reparação'

"Não pode, em suma, a Lei n. 6.729/79 ser convertida em escudo para que aquele, que impôs à outra parte uma obrigação gravosa, não se sinta vinculada às conseqüências dela decorrentes.

"No fundo, o que a Recorrente postula é que satisfeito o maximum previsto nos incisos I usque III adquire um 'bill' de indenidade, ficando isenta de 
reparar os prejuizos causal e logicamente decorrentes de sua já agora indiscutível infração contratual!"

14. Pois bem, foi quando do julgamento da já lembrada Ação Rescisória que houve oportunidade de ficar ainda mais esclarecido o problema dos limites da Lei especial perante o Direito comum, graças ao brilhante voto do ilustre Ministro Otávio Gallotti, conforme o seguinte tópico fundamental:

"Peço vênia, portanto, para insistir na tese que venho sustentando desde o julgamento da preliminar: o acórdão rescindendo não apreciou a alegação de negativa de vigência do inciso IV, porque, segundo disse, não fora ele objeto do recurso extraordinário. Afirmou mais: que ainda quando houvesse sido atacado tal dispositivo, não seria possível considerá-lo, uma vez que não fora com arrimo nele, mas no Direito comum, que a combatida indenização fora imposta.

Quanto ao artigo 23 é bom acautelar-se o julgador: a hipótese contemplada no seu caput não é a dos autos rescisão unilateral pelo concedente mas sim, a de nãoprorrogação de concessão que se extinguiu ao advento do seu tempo.

Adentrando a tese que, na ação rescisória, quer a autora ver sufragada pelo colendo Plenário, segundo a qual,

as indenizações admitidas em lei especial excluem as de direito comum,

peço vênia, ainda uma vez, aos seus ilustríssimos patronos para a ela não-aderir.

Em todas as espécies de relações entre sujeitos de direito é possivel dar disciplina normativa àquilo que lhes é específico. Assim, as relações de marido e mulher, de pais e filhos, de locador e locatário, de vendedor $e$ comprador, de comitente e comissário, de fabricante ou montador de automóveis e revendedor, ou dealer, desse produto, são submetidas, pelo legislador a um sistema 
especial de normas que não se pode arrogar a pretensão de prever, exaustivamente, eventos futuros e incertos.

Larenz, falando a respeito dos tipos contratuais regulados pela lei, adverte que

'a situação na qual o legislador, normalmente enquadra certos interesses, pode não se encontrar no caso particular de um contrato determinado que pode conter, adicionalmente, elementos que não são típicos (em tal contrato) e que tornam necessária uma apreciação diferente precisamente dessa questão.

Os tipos contratuais legais não são fixos, mas capazes de sofrer modificações diversas e, nesse sentido são tipos abertos. (Cf. Karl Larenz, Derecho Civil, Parte General, Editorales de Derecho Reunidas, p. 752).

No caso dos autos, uma certa situação não-típica, qual seja a de exigir um contratante, de outro, a realização de obras extensas e onerosas em imóvel de propriedade deste último, como condição de conclusão do negócio típico não sendo tal condição prevista na lei aplicável pode dar ensejo à operação que Larenz denomina interpretação complementar do contrato.

A possibilidade de introdução de outras cláusulas $e$ condições no negócio jurídico de concessão comercial de distribuição de veículos é, aliás, expressamente prevista no art. $1^{\circ}$, da Lei $n$. 6.729/79:

'A distribuição de veículos automotores, de via terrestre, efetivar-se-á através de concessão comercial entre produtores e distribuidores disciplinada por esta Lei e, no que não a contrariem, pelas convenções nela previstas e disposições contratuais.

Vê-se, pois, que o negócio jurídico de concessão comercial de distribuição de veículos automotores está aberto à pactuação, pelos interessados, de outros direitos e obrigações não-contemplados na Lei $n$. $6.729 / 79$. 
Se uma das partes é, assim, onerada sem que o contrato de concessão comercial preveja como disse indenizá-la na hipótese de rescisão unilateral, é induvidoso que a lesão patrimonial decorrente deve ser reparada, na conformidade do direito comum (art. 159, Código Civil).

O silêncio da lei, no entender da autora, armá-la-ia de exceção ao dever de indenizar que é de ordem geral, de todos exigivel, até mesmo do Estado; em hipótese em que o silêncio da mesma lei não impedia o concedente de exigir do concessionário a assunção de ônus nela não-previsto.

Tal exceção não existe senão - perdoem-me a tautologia nas leis de exceção, naquelas que singularizam um sujeito de direito em face da sociedade e dos demais sujeitos de direito. Exemplo conspícuo encontra-se na máxima Legibus solutus rex est a qual por certo não se aplica aos concedentes comerciais de distribuição de veículos.

Subjaz à argumentação da autora, nem sempre com a necessária clareza, a pretensão de ver tratado o contrato de concessão comercial como instrumento cerrado a qualquer influxo ou inspiração do direito comum ao qual seria impermeável - tal como se estivéssemos em regime de organização corporativa da economia e da sociedade.

A autonomia da vontade individual, de um lado, e, de outro, o monopólio legislativo da União, dos Estados e dos Municípios, têm levado o Supremo Tribunal a nãoreconhecer em convenções coletivas, ainda quando referidas na Constituição, tais as de natureza trabalhista, força derrogatória de princípios jurídicos e de normas legisladas.

Assim, se o contrato impôs ao concessionário comercial de distribuição de veículos um ônus 
particular, certo e determinado, não-previsto na lei especial, há de ser ele incluído na indenização devida à parte onerada, em caso de rescisão unilateral de contrato de concessão, segundo, as regras do direito comum aplicáveis às violações de contrato e ao dever jurídico de indenizar." (Ação Rescisória n. 1.273-9-PR, cit.).

\section{VII}

A Lei n. 6.729 e a Constituição de 1988

15. É pacífico que o advento de uma nova Constituição não subverte a ordem jurídica $a b$ imis fundamentis, mas tão-somente priva de eficácia todos os textos legais que colidam com seus princípios e disposições. Quando as leis anteriores se harmonizam com a nova Carta Magna, diz-se que se opera a sua recepção por ela, sem solução de continuidade em sua vigência e efetividade.

É o que, segundo me parece, ocorre com a Lei n. 6.729, não obstante algumas dúvidas surgidas sobre este ou aquele outro ponto.

Em primeiro lugar, poder-se-ia alegar que, sendo o dirigismo contratual de certa forma uma planificação obrigatória do direito de contratar, estaria ele em conflito com o Estatuto de 1988 que, logo no art. $1^{\circ}$, de manifesto caráter preambular, consagra a livre iniciativa como um dos fundamentos do Estado Democrático de Direito, para, depois, no art. 170, elevar a livre concorrência à categoria de um dos princípios da ordem econômica.

Além disso, temos o art. 174 que, de maneira peremptória, declara que o planejamento será determinante para o setor público e apenas indicativo para o setor privado. Não há, todavia, como confundir o planejamento exercido pelo Estado como agente econômico com a sua interferência a fim de pretraçar normas ao exercício do direito de contratar, estabelecendo limites à autonomia da vontade para preservar o justo equilíbrio nas relações entre grupos econômicos expostos ao predomínio de um deles. Nesse caso, a ação do Estado se baseia no preceito constitucional que prevê a repressão do abuso do poder econômico (art. 173, § $4^{\circ}$ ). 
Com o dirigismo contratual, em suma, ao invés de se reprimir $a$ posteriori um previsível abuso, em razão da estrutura oligopolística de dado setor da economia, previne-se a priori a ocorrência desse abuso mediante um sistema de normas que, sem suprimir a livre convenção, condiciona-a a certos parâmetros de natureza eqüitativa. Tal contrato, no entanto, é sempre consensual.

É claro que o dirigismo contratual implica certa planificação normativa, mas não pode esta ser confundida com o planejamento econômico de que trata o já lembrado art. 174 da Constituição atual.

Assim sendo, penso que a Lei, objeto de nossa análise, se concilia plenamente com as normas constitucionais supervenientes, sem ser afetada em sua vigência e eficácia.

Outra restrição invocada diz respeito ao art. 13, que conflitaria com a Carta Magna ao declarar que as mercadorias, objeto da concessão, deverão ser vendidas pelo concessionário ao preço fixado pelo concedente.

Pretende-se, a meu ver erroneamente, que, dado o primado da livre iniciativa e a excepcionalidade do controle de preços, nos termos da nova Carta, o concessionário teria adquirido o direito de fixar livremente o preço das mercadorias, objeto do contrato de concessão comercial.

Tal entendimento subverte a noção mesma de concessão comercial, a qual, como as próprias palavras estão dizendo, está adstrita à esfera da comercialização, sem invadir a área de produção atribuída ao concedente. Não creio, pois, que a lei não possa conferir ao concedente o direito de fixar os preços das mercadorias a serem praticados uniformemente por todos os concessionários integrantes de sua rede. A concorrência entre os concessionários viria subverter um dos valores que a Lei de regência visou alcançar, que é a igualdade dos concessionários entre si e perante o concedente no que se refere ao preço dos produtos, sem falar em outros casos de análoga paridade.

Aliás, o sistema de preços que, no meu entender, passou a viger nos domínios da indústria automobilística, é o dos preços programados, o qual implica certa fiscalização por parte do Poder Público, tal como se acha previsto no próprio Decreto que criou o Conselho Interministerial de Preços - CIP. em virtude de existência de oligopólio superada, porém, a inadmissível política de preços controlados "a priori", de que tanto se abusou à sombra da Carta de 1967/67, da qual não desencarnaram os mentores da chamada República Nova, tãoprematuramente envelhecida... 
Em conclusão, a posição do concedente e do concessionário, tal como prevista na Lei n. 6.729, foi igualmente preservada, sem sofrer modificação em qualquer de seus preceitos, a não ser as que resultaram do disposto na já citada Lei n. 8.132, de 26 de dezembro de 1990, que alterou a redação dos primitivos artigos, revogando o art. 14, o que não conflita com as teses desenvolvidas no presente estudo.

São Paulo, dezembro de 1996. 


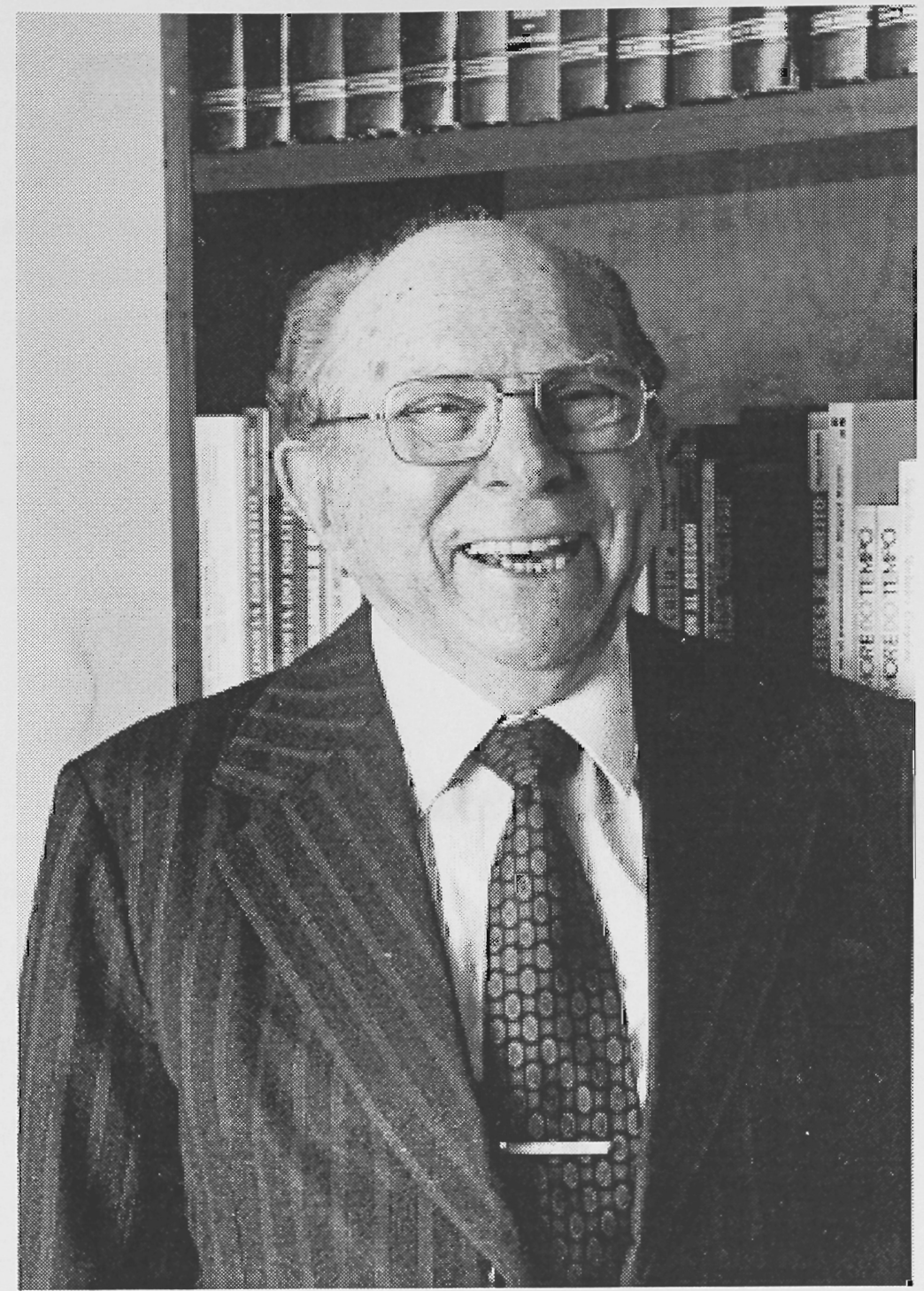

Prof. Dr. Miguel Reale 